\title{
Fossil insects from the Late Oligocene Enspel Lagerstätte and their palaeobiogeographic and palaeoclimatic significance
}

\author{
Sonja Wedmann • Markus Poschmann • \\ Thomas Hörnschemeyer
}

Received: 7 September 2009 /Revised: 30 September 2009 / Accepted: 26 October 2009/Published online: 19 November 2009

(C) The Author(s) 2009. This article is published with open access at Springerlink.com

\begin{abstract}
Fossil insects can provide unique insights into evolutionary history, and their study has become increasingly important in recent decades. In this paper, we give an overview of the insect taphocoenosis from the upper Oligocene Enspel Lagerstätte (Germany) and discuss taphonomic similarities with other localities. Among the fossil insects identified, terrestrial groups are highly dominant, with march flies (Bibionidae) and weevils (Curculionoidea) being the most common groups; aquatic insects are rare. We provide a detailed survey of the represented taxa, including new records of a predaceous diving beetle (Dytiscidae), a soldier beetle (Cantharidae) and mayfly larvae (Ephemeroptera). Updated information on the ants (Formicidae) and reticulated beetles (Cupedidae) is reported. The palaeoclimatic and palaeobiogeographic inferences that can be drawn from the represented groups are discussed. Studies on the insects from Enspel indicate a warm temperate climate. Several records
\end{abstract}

This article is a contribution to the special issue "Fossil-Lagerstätte Enspel-exceptional preservation in an Upper Oligocene maar"

\author{
S. Wedmann $(\bowtie)$ \\ Forschungsstation Grube Messel, Forschungsinstitut Senckenberg, \\ Markstraße 35, \\ 64409 Messel, Germany \\ e-mail: Sonja.Wedmann@senckenberg.de \\ M. Poschmann \\ Generaldirektion Kulturelles Erbe RLP, \\ Referat Erdgeschichte, \\ Große Langgasse 29, \\ 55116 Mainz, Germany \\ T. Hörnschemeyer \\ Johann-Friedrich-Blumenbach-Institut für \\ Zoologie \& Anthropologie, Abteilung Morphologie \& Systematik \\ mit Zoologischem Museum, Georg-August-Universität, \\ Berliner Str. 28, \\ 37073 Göttingen, Germany
}

document that the distribution of many insect groups in the Oligocene was distinctly wider than it is today.

Keywords Enspel · Germany · Insects · Oligocene · Palaeobiogeography $\cdot$ Paleogene $\cdot$ Taphocoenosis

\section{Introduction}

Fossil insects have been found in a wide range of different deposits, and the record of insect fossils is surprisingly diverse. Ambers around the world have yielded huge numbers of insect inclusions, but their record from other deposits is probably equally large (e.g. Rasnitsyn and Quicke 2002; Grimaldi and Engel 2005). Fossils provide valuable insights into the evolutionary history of insect groups, the ages of lineages and also radiations and extinctions. Studies on the fossils of Tertiary insects additionally allow for paleoecological inferences to be drawn on the former ecosystem or even on the climate via comparisons with their extant relatives. Exhaustive surveys of insect faunas are available for relatively few Tertiary deposits, but their number continues to grow. Important sites of Tertiary non-amber insect taphocoenoses from Germany include the Pliocene fossil site Willershausen (e.g. Gersdorf 1968; Weidner 1979; Kohring and Schlüter 1993), the Miocene Randecker Maar (e.g. Armbruster 1938; Schawaller 1986; Naumann 1987; Kühbander and Schleich 1994; Ansorge and Kohring 1995, Kotthoff 2002, 2005, Joachim 2008), the Oligocene of Rott (e.g. Heyden 1862; Statz 1930, 1938, 1939, 1940; Willmann 1976; Kohring 1991; Hellmund and Hellmund 1993; Lutz 1996), the Eocene Eckfeld Maar (e.g., Lutz 1991, 1993; Wappler 2003; Wappler and Engel 2003; Wappler and Andersen 2004; Wappler et al. 2004; Wappler and Heiss 2006a; 
Wappler and Ben-Dov 2008; Dlussky et al. 2008, 2009; Wedmann et al. 2009) and the Eocene Grube Messel (e.g., Meunier 1921; Lutz 1990, Wedmann 2005, Wappler 2006; Wappler and Heiss 2006b; Wedmann et al. 2007; Wedmann and Makarkin 2007; Wedmann and Yeates 2008; Dlussky et al. 2008, 2009; Wedmann et al. 2009; Schmied 2009), among others.

Insects are among the most commonly found fossils in the upper Oligocene deposits of Enspel. A comprehensive survey of the fossil insects recorded and described from Enspel is given in the following sections. Enspel complements the record of the insect taphocoenoses mentioned above by providing a particularly interesting opportunity to compare its fauna with the insect fauna from Rott. The age of both Rott and Enspel is upper Oligocene, about 24 and 25 mya, respectively (Mörs 1995; Storch et al. 1996; Mertz et al. 2007), and the fossil sites are geographically located only about $50 \mathrm{~km}$ apart. Furthermore, Enspel represents another locality with a volcanic origin, where the deposition of the fossiliferous sediments took place in a deep, meromictic lake.

As in many former lakes of volcanic origin, the composition of the preserved insect fauna of Enspel is taphonomically biased towards a dominance of beetles (Coleoptera) (Fig. 1). Among the fossil insects from Enspel that could be determined to ordinal level (Wedmann 2000), beetles comprise $52.4 \%$, flies and midges (Diptera) 23.9\%, ants, bees and wasps (Hymenoptera) $12.4 \%$ and caddisflies (Trichoptera) $6.4 \%$. The latter group is mostly represented by larval cases. Several other insect groups are present only as a few fossils; these make up the remaining $4.9 \%$ of the insects identified to date. Several other fossil sites also show a dominance of beetles in their taphocoenoses, such as Orapa (Botswana), Menat (France), Messel and Eckfeld (Piton 1940; Lutz 1990; Rayner 1993; Wedmann 2000; Wappler 2003). All of these sites are former lakes that came into existence as a result of some kind of volcanic explosion; therefore, these lakes were comparatively deep in relation to their former surface. Insect taphocoenoses from lakes that presumably were not so deep often deviate from this dominance of beetles [e.g. Florissant (Scudder 1890), Rott (Statz 1940; Lutz 1996), Willershausen (Wedmann 2000)]. Some possible underlying taphonomic reasons for this distribution have been discussed from various viewpoints (e.g. Wilson 1980; Lutz 1997; Lutz and Kaulfuß 2006), but there are still many unresolved questions that await further analysis.

The deep lakes also have other similarities in addition to their taphonomic resemblance, such as the preservation of the original metallic structural colours in some insects. Structural colours are preserved in the fossils at Enspel, Messel (Lutz 1990; Hörnschemeyer and Wedmann 1994), Eckfeld (Lutz 1991, Wappler 2003) and Menat (Piton

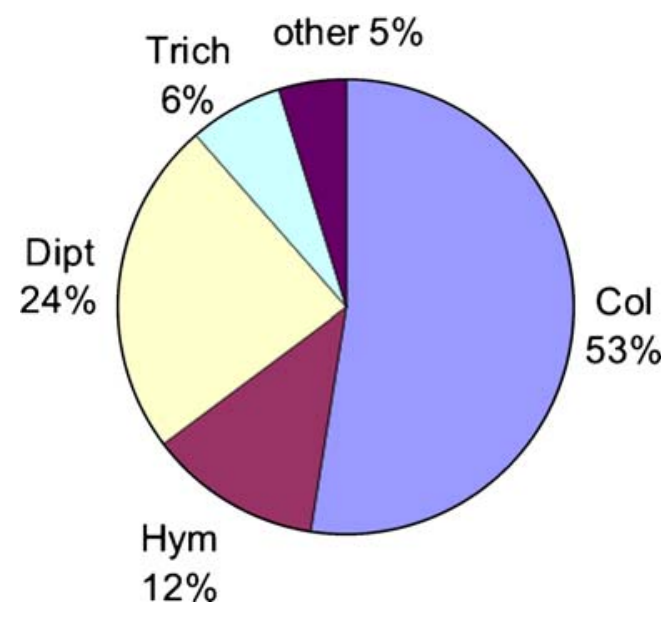

Fig. 1 Composition of the insect taphocoenosis from Enspel, based on the analysis by Wedmann (2000). All fossils that could not be determined to order level are excluded from this figure. Col Coleoptera, beetles; Hym Hymenoptera, i.e. bees, ants, wasps, etc; Dipt Diptera, midges and flies; Trich Trichoptera, caddisflies; other other insect groups. $n=4222$

1940). When examined with a transmission electron microscope, a multilayer reflector was identified in a fossil from Messel (Parker and McKenzie 2003). This kind of colour preservation is not restricted to these sites, but has also been found in the Eocene Geiseltal (Germany). For Enspel, analysis of insect cuticles even yielded the oldest preserved traces of chitin (Stankiewicz et al. 1997). Examination of the molecular preservation of the insect fossils suggests that the aliphatic components of the cuticles are not derived from the host sediment via migration (Gupta et al. 2007).

\section{Material and methods}

All fossils are currently held at the Generaldirektion Kulturelles Erbe RLP, Referat Erdgeschichte, Mainz, Germany. Over the long term, they will be deposited in the Naturhistorisches Museum Mainz/Landessammlung für Naturkunde Rheinland-Pfalz.

\section{The fossil insect taphocoenosis from Enspel}

The insect taphocoenosis (Fig. 1) comprises mostly terrestrial groups that inhabited the surroundings of the former lake, while aquatic insects that lived at least temporarily in the lake are very rare.

Terrestrial insects

Among the terrestrial insects, beetles (Coleoptera) are the most common group, with the majority of beetle fossils being weevils (Curculionoidea) (Fig. 2a). The size of the 
Fig. 2 Beetles (Coleoptera)

from Enspel. a Weevil

(Curculionoidea), coll. no.

PE2005/5033-LS;

b archostematan beetle,

Cupedidae, possibly

Tetraphalerus, coll. no. 6378;

c rove beetle (Staphylinidae),

coll. no. PE2007/5001-LS;

d jewel beetle (Buprestidae),

coll. no. PE2003/5002-LS;

e soldier beetle (Cantharidae), coll. no. PE2007/5006-LS.

Scale bars: $5 \mathrm{~mm}$
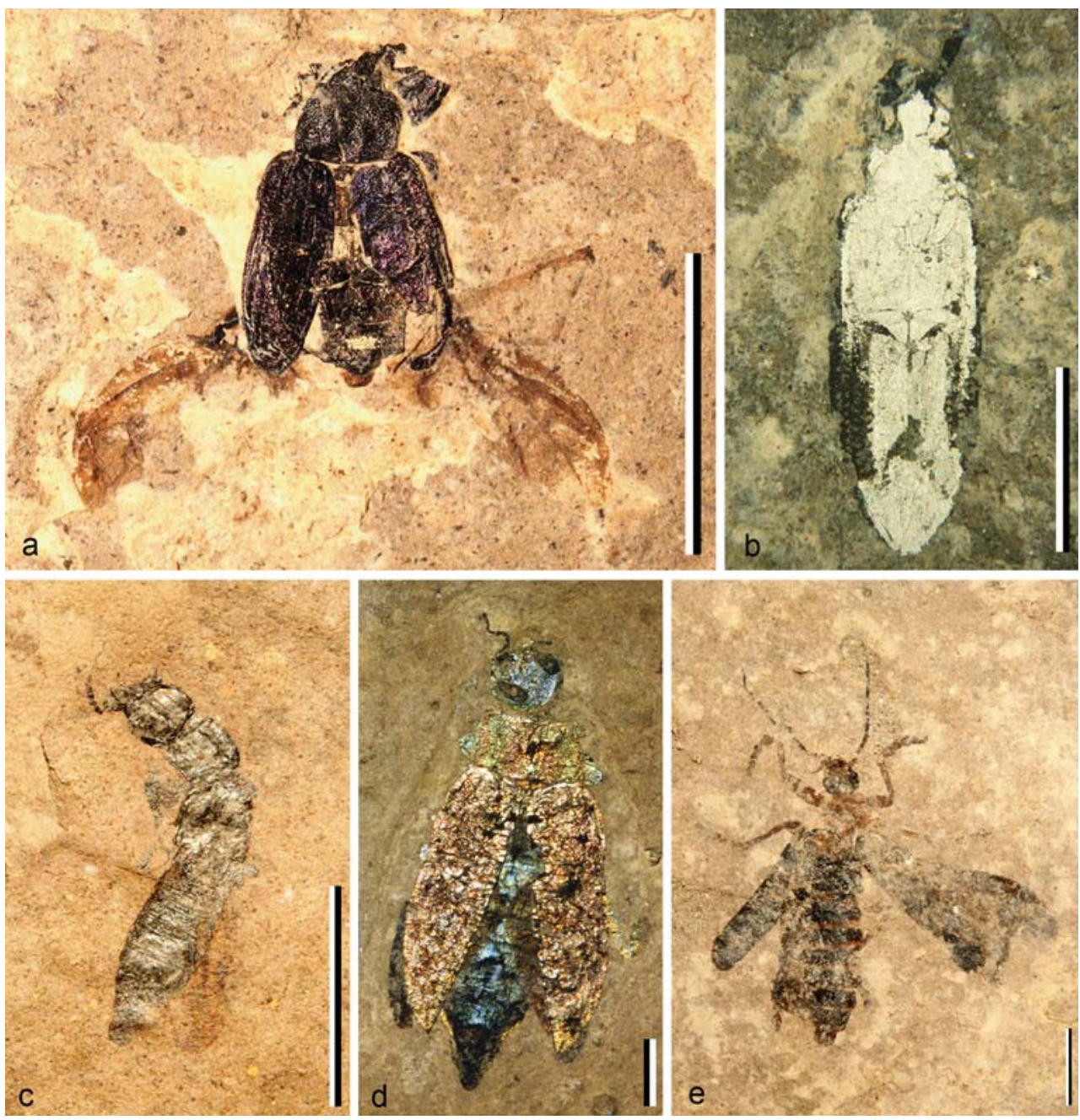

weevils ranges mostly from 4 to $10 \mathrm{~mm}$. Their cuticle sometimes has a blue structural colour preservation, but mostly it is simply black. Interestingly, weevils are a part of the diet of the only fish species recorded from Enspel, Palaeorutilus enspelensis (Böhme, 1996). This is documented by one specimen, which has remains of several weevils in its digestive tract (see figures in Wedmann 2000: plate 5 and Figs. 1 and 3). Additionally, a lot of coprolites have been found, consisting mostly of weevil remains. These coprolites were most likely produced by Palaeorutilus, and their fossils indicate that this cyprinid fish apparently preyed upon weevils regularly (Wedmann 2000). That Palaeorutilus preyed upon insects has also been confirmed by stable isotope analysis (Schweizer et al. 2006). Other beetle families are much rarer. Archostemata are represented in Enspel by at least two different species of Cupedidae (Fig. 2b). While cupedid beetles today do not occur in Europe, fossil specimens are recorded at various European Tertiary deposits (e.g. Tröster 1993; Gersdorf 1976). Among the ground beetles (Carabidae) several taxa are present (Wedmann 2000). A particular species with bluish-green elytra dominates, which may be related to its possibly

hydrophilic lifestyle near the shoreline of the lake. Rove beetles (Staphylinidae) are characterized by their very short elytra (Fig. 2c). Albeit rare at Enspel, the diversity of rove beetles seems to be quite high, with sizes that range from about 3 to $21 \mathrm{~mm}$. In contrast to Enspel, rove beetles are abundant at Rott where they comprise over 7\% of the beetle fossils (Statz 1938). Jewel beetles (Buprestidae) are conspicuous because of their metallic structural colours (Fig. 2d). Representatives of both Buprestinae and Agrilinae are present (Wedmann 2000). The recorded click beetles (Elateridae) have a size spectrum from 10 to $25 \mathrm{~mm}$ and are quite rare. Leaf beetles (Chrysomelidae) are more common and often display striking structural colours (Wedmann 2000). The beetles belonging to the families Cantharidae (Fig. 2e), Histeridae, Silphidae(?), Throscidae or Eucnemidae, Lampyridae, Scarabaeoidea, Lathridiidae(?) and Cerambycidae or Oedemeridae are only represented by very few specimens, respectively.

Midges and flies (Diptera) comprise about one quarter of the determined insects, but their preserved diversity is quite low. Over $95 \%$ of the dipteran fossils are representatives of the march flies (Bibionidae) which are the most common fossil insects at Enspel. Among the bibionids, members of 
the genus Bibio (Fig. 3a), which today occur in temperate climates, are by far the most dominant, while representatives of the thermophilic genus Plecia (Fig. 3b) are rare. The wealth of bibionid fossils in various stages of disarticulation has enabled the reconstruction of the disarticulation process and allowed to make inferences on stagnant conditions at the former lake bottom (Wedmann 1998a, 2000). Other dipteran taxa are crane flies (Tipulidae), snipe flies (Rhagionidae), soldier flies (Stratiomyidae), robber flies (Asilidae) and flower flies (Syrphidae). The most unexpected record to date has been that of a tsetse-fly (Glossinidae) (Wedmann 2000, 2001; Poschmann and Wedmann 2005), which possibly is conspecific with Glossina oligocenus from the late Eocene fossil site Florissant (USA) (Wedmann 2000). Together with the records from Florissant, these are the only fossil records of this family which today occurs only in Africa.

Among the hymenopteran insects, ants (Formicidae) comprise about half of the fossils (Wedmann 2000). They are mostly winged males and females; as at other fossil sites, ant workers are very rare. A preliminary systematic survey of the ants was conducted, and representatives of
Dolichoderinae, Formicinae, Ponerinae and Myrmicinae (Fig. 3c) were recognized among the examined specimens (personal communication G. Dlussky, Moscow University). The ant fauna of Enspel shows similarities to the faunas of Rott and some Miocene deposits, but clearly differs from the early Oligocene fossil sites Bembridge (UK) and Kleinkembs (France), primarily in terms of the high proportion of Myrmicinae (Fig. 3c), which mainly belong to the formal morphogenus Paraphaenogaster (Dlussky and Rasnitsyn 2007; personal communication G. Dlussky). There are few fossil records of parasitic wasps of the families Trigonalidae, Diapriidae, Ichneumonidae and Chrysididae. A wide range of phytophagous groups was also reported, including basal Hymenoptera, such as common sawflies (Tenthredinidae), horntails (Siricidae) (Wedmann 1998b), and the very rare Blasticotomidae. In addition to several stinging wasps, such as yellow jackets (Vespidae) and spider wasps (Pompiliidae), there are also several fossil bees (Apidae), that is, several bumblebees (Bombinae) and honey bees (Fig. 3d). The honey bees from Enspel are conspecific with Apis henshawi from the fossil site Rott. An analysis of the wing venation of the extant
Fig. 3 Midges (Diptera) and hymenopteran insects (Hymenoptera) from Enspel. a Female march fly (Bibionidae), Bibio sp., coll. no. 5189 ; b female march fly (Bibionidae), probably Plecia sp., coll. no. PE2008/5005-LS; c myrmicine ant (Formicidae: Myrmicinae), coll. no. 5132; d honey bee Apis henshawi (Apidae), partly pyritic, coll. no. 236. Scale bars: $5 \mathrm{~mm}$
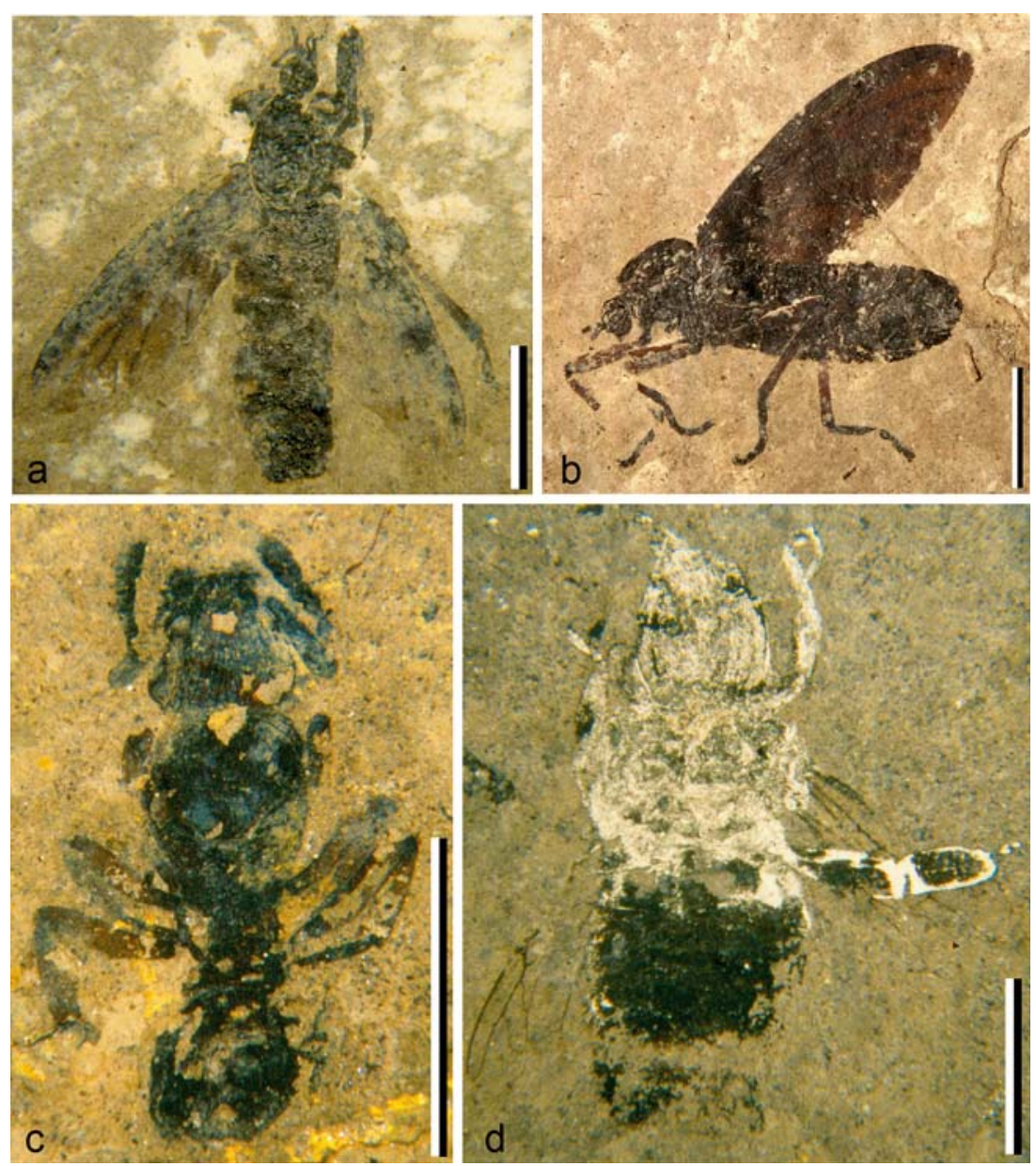
species of Apis revealed that the wing venation of Apis henshawi is most similar to that of extant Apis dorsata, which is among the more basal species of Apis. It can be inferred that the Oligocene $A$. henshawi was eusocial and probably had an open-air nest like $A$. dorsata and other basal species of Apis (Wedmann 2000).

Hemipteran insects are comparatively rare in Enspel, but they are represented by quite a wide range of groups. Members of both Cicadomorpha and Fulgoromorpha are present, as are several groups of Sternorrhyncha, such as aphids (Aphidoidea) and jumping plantlice (Psylloidea) (Wedmann 2000). Bugs (Heteroptera) are represented not only by several terrestrial groups, but also by aquatic taxa (see below). The terrestrial groups comprise plant bugs (Miridae), stink bugs (Pentatomidae) (Fig. 4a) and one flat bug (Aradidae), which was described as Neuroctenus enspelensis by Wappler and Heiss (2006b). Earwigs (Dermaptera) are represented by several fossils, often showing only the last segments of the abdomen and the forceps, but sometimes also the complete body (Fig. 4b). Termites (Isoptera) are represented mostly by wing remains of the extinct genus Ulmeriella (Fig. 4c), which belongs to the Hodotermitidae.

Several more terrestrial insect groups are represented with only one or two fossils. This is the case for gryllids and tettigoniids (Orthoptera) (Poschmann and Wedmann 2005), praying mantises (Mantodea), cockroaches (Blattodea), thrips (Thysanoptera) (Fig. 4d), snakeflies (Raphidioptera), owlflies and lacewings (Neuroptera), scorpionflies (Mecoptera) and butterflies (Lepidoptera) (Wedmann 2000).

Altogether, there are many xylophagous groups among the terrestrial taxa which indicate densely wooded surroundings in the close vicinity of the former lake. Numerous parasitic insects show the high complexity of the former ecosystem. It seems that although there were repeated volcanic activities, these did not influence the ecosystem in such a way that the fauna became impoverished for longer periods of time.

\section{Aquatic insects}

Aquatic insects from Enspel mainly consist of case-making caddisflies (Trichoptera, Integripalpia), which constitute about $6 \%$ of the insect fossils determined to ordinal level by Wedmann (2000). Adult caddisflies are only represented by very few fossils, which is probably due to their large wing surface/body weight ratio preventing them from sinking to the lake bottom (cf. Martinez-Delclòs and Martinell 1993). Most "caddisfly fossils" are larval cases, i.e. trace fossils left by the activity of their larvae (Zherikhin 2002). There is a wide variety of different case types differing both in shape and in the materials used to construct the case wall, including forms made of sand

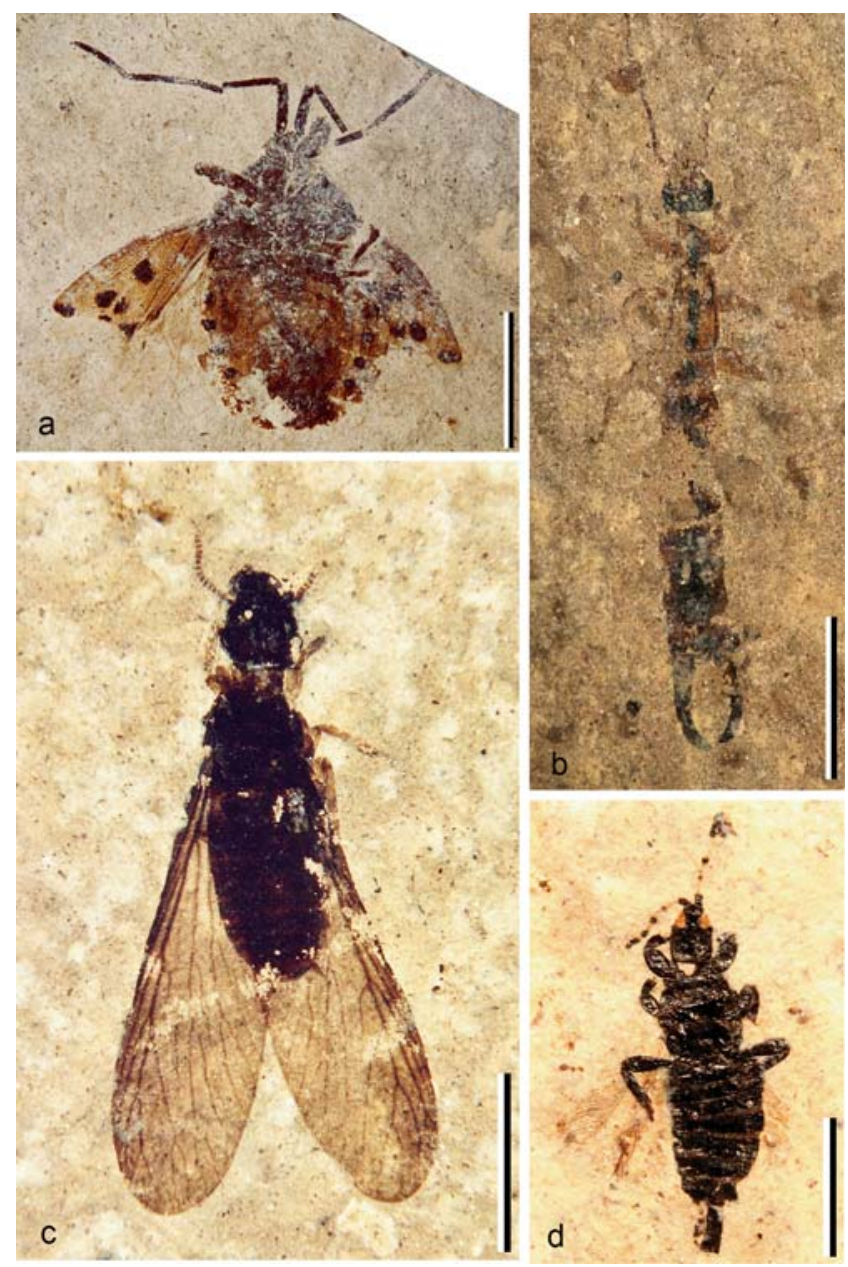

Fig. 4 Representatives of rare insect groups from Enspel. a Stink bug (Heteroptera, Pentatomidae), coll. no. PE2003/5014-LS; b earwig (Dermaptera), coll. no. PE2006/5017-LS; c termite (Isoptera), probably Ulmeriella sp., coll. no. PE2004/5297-LS; d minute thrips (Thysanoptera), coll. no. PE2005/5037-LS. Scale bars: (d) $1 \mathrm{~mm}$; $(\mathbf{a}, \mathbf{b}, \mathbf{c}) 5 \mathrm{~mm}$

grains, seeds (Fig. 5a), small twigs (Fig. 5b) and cut leaf fragments, and some show agglutinated larger twigs or empty cases in order to prevent predators from swallowing the whole cases (Poschmann 2006). One example is even made of sponge remains, including spicules and gemmulae. Although similar cases could potentially be produced by other animals, such as polychaete annelids or aquatic lepidopteran larvae, the assemblage and the constructional variety of the cases from Enspel are quite characteristic for caddisfly larvae, and some examples are even indicative of particular families; for example, the flattened cases made of sand with lateral flanges and a cowl over their anterior opening suggest the presence of the caddisfly family Molannidae in the ancient Lake Enspel ecosystem. While most of the caddisfly cases do not show parts of the actual larva in situ, a closer examination has revealed that about $8 \%$ show remains of the larval producer, which is quite 


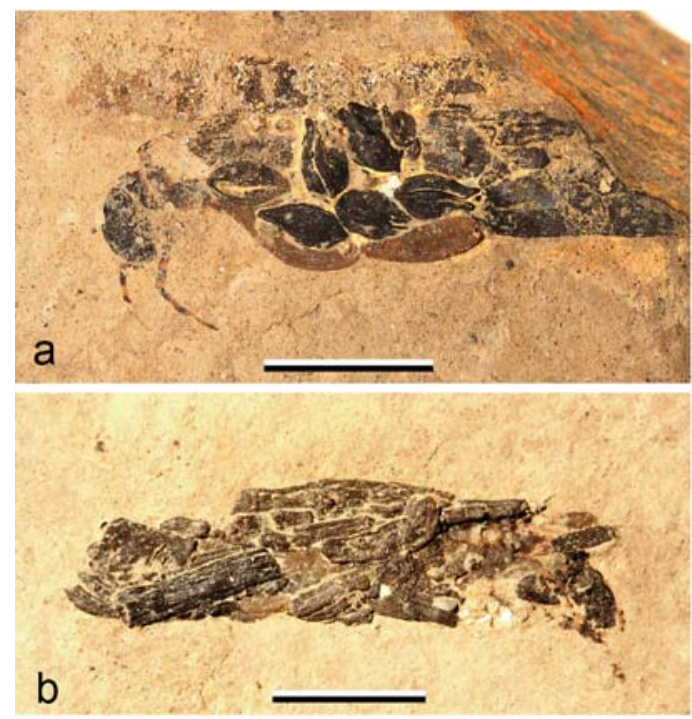

Fig. 5 Caddisfly larvae (Trichoptera) and aquatic beetles from Enspel. a Limnephilid(?) caddisfly larva which used mainly seeds for its case construction, coll. no. PE2005/5006-LS; b caddisfly larva which built its case using spirally arranged plant stems, coll. no. PE2005/5007-LS;

exceptional among comparable Lagerstätten. It is possible that the true number of dead larvae is even higher because the bodily preserved larvae may escape observation when concealed within intact cases. Based on both the construction of the cases and the morphological features exhibited by the larval remains, Poschmann (2006) suggested that some of these fossils can be assigned, with reservations, to the caddisfly family Limnephilidae. Both families, Molannidae and Limnephilidae, are, with few exceptions, nowadays confined to the northern hemisphere, with the latter family clearly preferring temperate regions (Hickin 1967). In terms of taphonomy, the caddisfly larvae probably inhabited the shallow lake margins, but if individuals were transported into the anaerobic monimolimnion, they were susceptible to asphyxiation and at the same time withdrawn from the action of potential predators, including the cyprinid fish Palaeorutilus (Poschmann 2006).

Aquatic beetles are quite rare, with two families recorded from Enspel: the Hydrophilidae and, as a new record, the Dytiscidae. Hydrophilid beetles are represented by the species Hydrobiomorpha enspelense Wedmann, 2000 (Fig. 5c), which was recently also recorded from the Oligocene deposits of Seifhennersdorf, Germany (Fikácek et al. 2008). Since the extant species of Hydrobiomorpha are distributed only in tropical to subtropical regions of both the Old and New World, the fossil occurrences of this taxon indicate a formerly wider distribution (Wedmann 2000; Fikácek et al. 2008). The first record of a predaceous diving beetle (Dytiscidae) from Enspel is an isolated elytron (Coll. No. PE97/5672) that is shown in Wedmann (2000: plate 5, Fig. 7; present article, Fig. 5d), which until now has

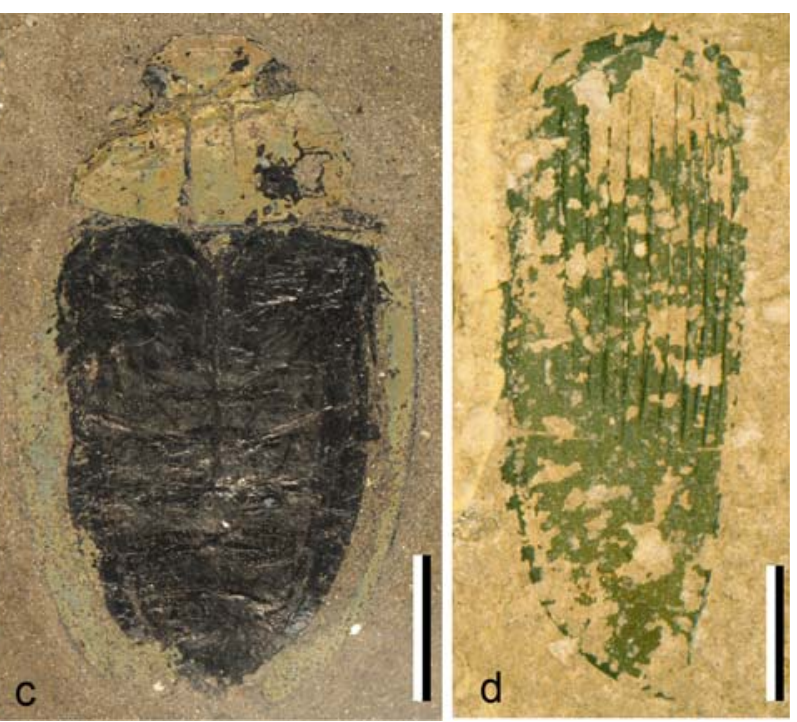

c water scavenger beetle Hydrobiomporpha enspelense (Hydrophilidae), coll. no. BAG; $\mathbf{d}$ isolated elytron of a female predaceous diving beetle (Dytiscidae), coll. no. PE97/5672-LS. Scale bars: $5 \mathrm{~mm}$

been classified as a Coleoptera indet. Due to the characteristic sculpture on its surface, consisting of ten longitudinal striae on the basal half of the elytron, and its length of $25.3 \mathrm{~mm}$, this elytron can be identified as belonging to a female dytiscine beetle. Several genera of dytiscine beetles exhibit sexual dimorphism in the surface structure of their elytra (e.g. Miller 2003), but the ten striae present in the Enspel specimen closely resemble those present in extant female Dytiscus species. Consequently, this fossil is assigned to an unidentified species of Dytiscus. The peculiar structure of the elytra of several female dytiscid beetle taxa is thought to be connected with sexual selection: the striae probably evolved as counter-adaptation to overcome the male grasping device of many dytiscids (Miller 2003). The fossil species Dytiscus avunculus was described by Heyden (1862) on the basis of a female isolated elytron from Tertiary deposits from Höhgau that also showed the same ten shortened striae. These fossils show that the evolutionary "arms race" of the sexes over mating decisions (Miller 2003) was already established in the Oligocene.

There is only a sparse record of mayflies (Ephemeroptera), consisting of fragmentarily preserved larvae showing the characteristic caudal filaments.

While only one adult damselfly (Odonata: Zygoptera) has been found in Enspel, several dragonflies (Odonata: Anisoptera) have been recorded, comprising both larvae and remains of the adults (Wedmann 2000) (Fig. 6). Most fossils belong to the darners (Aeshnidae), but the morphological diversity seen among the larvae (Fig. 6a-c) suggests the presence of further, hitherto undetermined dragonfly 
Fig. 6 Dragonflies (Odonata: Anisoptera) from Enspel. a Dragonfly larva, possibly Aeshnidae, coll. no. PE2006/5019-LS; b undetermined dragonfly larva, coll. no. PE2006/5022-LS; c undetermined dragonfly larva, coll. no. PE2007/5005-LS. d isolated thorax with both forewings of an adult aeshnid dragonfly (Aeshnidae), probably Oligaeschna jungi, coll. no. PE2005/5032-LS. Scale bars: $5 \mathrm{~mm}$
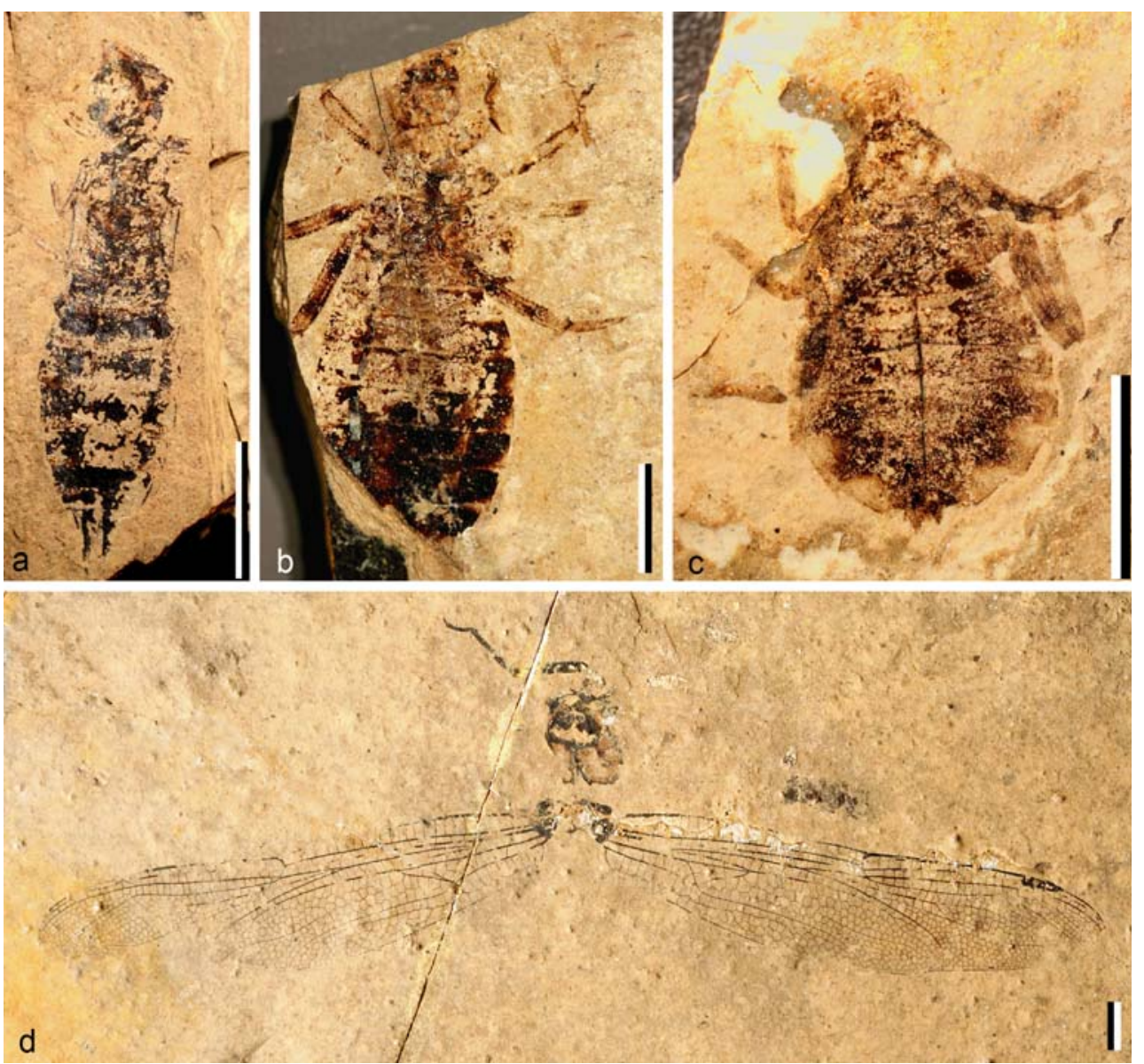

families. Several fossils of adult specimens belong to the species Oligaeschna jungi Piton and Theobald, 1939 (Fig. 6d), previously recorded from the upper Oligocene locality Puy-de-Mur (Auvergne, France) (Piton and Theobald 1939). A leaf with characteristic marks of damselfly egg-sets has also been found (Poschmann and Wedmann 2005).

Both larvae and adults of giant water bugs (Belostomatidae) are present (Wedmann 2000; Poschmann and Wedmann 2005). For dragonflies, the record of larvae of these insects proves that they were autochthonous aquatic insects in the former Lake Enspel. Water striders (Gerridae) are represented by only one fossil.

Among the obligatory aquatic insects that were not able to fly to the former Lake Enspel are the larvae of dragonflies and mayflies, the larvae of the giant water bugs and the producers of the numerous caddisfly cases. It seems probable that these insects lived directly in the former lake, but it is also possible that some lived in streaming water (Wedmann 2000). Remains of aquatic insects have been found at all digging sites, which are distributed widely over the fossil site, so it is very unlikely that they were transported into the lake by an inlet. Additionally, insects that obligatorily live in streaming water have not yet been identified. It can be concluded that the insects do not indicate the presence of a stream that flowed into the lake (Wedmann 2000), which is supported by Schindler and Wuttke (2010, this issue).

It is most likely that the aquatic insects lived in the shore area of the former Lake Enspel. The presence of predaceous dragonfly larvae and larvae of giant water bugs indicates that there was a complex ecosystem present-at least intermittently. Late larval stages of dragonflies indicate that Lake Enspel could be inhabited for at least several months, if not years, at a time. All aquatic insects together indicate that the former lake Enspel had a probably narrow, but richly inhabited shore area (Wedmann 2000). The relative scarcity of aquatic insects can be explained by the fact that they lived near the shore and, under normal conditions, only accidentally ended up in the deep and oxygen-free parts of the lake whose former sediments nowadays form the fossil site (Wedmann 2000).

\section{Palaeoclimatic and palaeobiogeographic implications}

In terms of the climatic demands, the composition of the insect groups from Enspel can be described as a kind of 
"mixed fauna" (Wedmann 2000, 2001). Several insect taxa have been found that nowadays do not occur in cool temperate Europe. These include giant water bugs (Belostomatidae), which today live mostly in warm climates and whose northernmost representatives can be found in southern Europe. The genus Hydrobiomorpha of the giant water scavenger beetles (Hydrophilidae) nowadays occurs mostly in tropical to warm temperate climates. A horntail (Hymenoptera: Siricidae) belonging to either Eriotremex or Afrotremex was recorded. These two extant horntail genera are native to the Oriental region and in Central Africa, respectively. Termites were represented by the extinct genus Ulmeriella, which was distributed in warm temperate climates on the Northern Hemisphere (Emerson 1968). Other records of Ulmeriella come from Oligocene to Pliocene fossil sites (Emerson 1968), and extinction occurred apparently during the onset of the ice ages. Among the march flies (Bibionidae), the genus Plecia alludes to tropical to warm temperate climates. For tsetse-flies, the climatic implications could be lower than one would assume when the high climatic demands of extant Glossinidae are considered. Extant tsetse-flies are very warm-adapted, but a phylogenetic analysis of the fossil species shows that this might not have been the case for the fossil taxa. The fossils do not belong to the extant group, which is adapted to tropical and subtropical climates (Wedmann 2000, 2001). Indicators for a cool temperate climate are the snake fly (Raphidioptera), the blasticotomid hymenopteran, the presence of bumblebees (Apidae: Bombinae) and the dominance of the genus Bibio among the march flies (Bibionidae).

From the Eocene, fossil insect faunas have been reported that show a mixed occurrence of taxa, which we nowadays regard as "temperate" and "tropical to subtropical" faunal elements (e.g. Wheeler 1910; Archibald and Mathewes 2000). Several explanations have been proposed for this mixed taxa (e.g. Wheeler 1910), but the most convincing was presented by Archibald and Farrel (2003), who suggested that a possible explanation for the "mixed" Eocene faunas, consisting of tropical and temperate components, was the higher equability of the climate in the Eocene, i.e. the reduced thermal seasonality. Ivany et al. (2000) found that the climate of the early Oligocene was more seasonal and had cooler winters than that of the late Eocene. A heightened temperature variability may have played a role in faunal turnover across the Eocene/ Oligocene boundary (Ivany et al. 2000), implying a higher degree of co-occurrence of taxa in the more equable Eocene than in the more seasonal Oligocene climate.

As outlined above, the Upper Oligocene insect fauna from Enspel shows a mix of today's temperate and warmadapted insect groups, but not of subtropical or even tropical ones. For those taxa, which today need tropical temperatures, it is considered more likely that the climatic requirements of the respective taxa in the Oligocene differed from those of the extant groups, as has been explained above for the tsetse-flies. It can therefore be concluded that the insects, like the Enspel taphoflora (Uhl and Herrmann 2010, this issue), indicate a warm temperate climate in which some taxa were probably existing at the margin of their climatic tolerance. Taxa that could only exist in more equable and warm climatic conditions became extinct at the Eocene-Oligocene border, while many less sensitive taxa, such as those recorded from Enspel, continued to live in sub-optimal climatic conditions, perhaps until they became extinct in Europe during the ice ages (Wedmann 2001).

With regard to palaeobiogeography, there are several taxa present in the taphocoenosis of Enspel that today do not occur in Europe. The most prominent example is the tsetse-fly (Glossinidae), with only one additional fossil record from the lower Oligocene of Florissant (Grimaldi 1992). All living extant species occur only in Africa where they live in rainforests or in the riparian vegetation of savannas. Cupedidae (Coleoptera) today have an almost worldwide distribution, with the exception of Europe. However, in addition to the records from Enspel, several other fossils from the Tertiary of Europe document their former presence up until the Pliocene (Gersdorf 1976), and their extinction from Europe may be connected with the ice ages (Wedmann 2000). The extant species of the flat bug Neuroctenus are mainly distributed in the tropics and subtropics, with relatively few representatives in the EastPalaearctic region and none in Europe (Wappler and Heiss 2006a). Fossil species of this genus are recorded from the Eocene fossil sites of Messel and Eckfeld, both in Germany (Wappler and Heiss 2006b, c), which confirms a formerly wider distribution of the genus. Together with the records of the horntail, the extant genera Plecia and Hydrobiomorpha, extinct Ulmeriella and the giant water bugs, already mentioned above, several fossils from Enspel confirm a much wider distribution of many insect groups during the Tertiary. This has been documented for many more insects from a wide range of fossil sites (e.g. Grimaldi and Engel 2005). One should be extremely cautious in drawing conclusions on the evolutionary or biogeographical history of insects based solely on present-day distributions. A recent example of this is the discovery of a Miocene honey bee (Apis nearctica) in North America (Engel et al. 2009). Especially for insects, the fossil record is still very scarce, but continued investigations can yield exiting new insights on the evolution of biodiversity and biogeography.

Acknowledgements We would like to thank Dr. Michael Wuttke, Mainz, for his support and the loan of the fossils, Prof. Dr. Gennady Dlussky, Moskow, for advice concerning special insect taxa and 
Mrs. Uta Kiel, Messel, for her help with preparing the figures. We thank Dr. Sam W. Heads, Champaign, and Prof. Dr. Carsten Brauckmann, Clausthal-Zellerfeld, for reviewing the manuscript, and Dr. Sam W. Heads for additionally correcting the English.

Open Access This article is distributed under the terms of the Creative Commons Attribution Noncommercial License which permits any noncommercial use, distribution, and reproduction in any medium, provided the original author(s) and source are credited.

\section{References}

Ansorge J, Kohring R (1995) Insekten aus dem Randecker Maar. Fossilien 2:80-90

Archibald B, Farrel BD (2003) Wheeler's dilemma. In: Krzeminska E, Krzeminski W (eds) Proc 2nd Congress Palaeoentomol "Fossil Insects". Acta Zool Cracoviensia 46[Suppl]:17-23

Archibald SB, Mathewes RW (2000) Early Eocene insects from Quilchena, British Columbia, and their paleoclimatic implications. Can J Zool 78:1441-1462

Armbruster L (1938) Versteinerte Honigbienen aus dem obermiozänen Randecker Maar. Arch Bienenkunde 19:1-48, 73-93, 97-133

Böhme M (1996) Revision der oligozänen und untermiozänen Vertreter der Gattung Palaeoleuciscus (Teleostei, Cyprinidae) Mitteleuropas. Dissertation. University of Leipzig, Leipzig

Dlussky G, Rasnitsyn AP (2007) Paleontological record and stages of ant evolution (in Russian). Uspekhi Sovremennoy Biol 127:118-134

Dlussky GM, Wappler T, Wedmann S (2008) New middle Eocene formicid species from Germany and the evolution of weaver ants. Acta Palaeontol Pol 53:615-626

Dlussky GM, Wappler T, Wedmann S (2009) Fossil ants of the genus Gesomyrmex Mayr (Hymenoptera, Formicidae) from the Eocene of Europe and remarks on the evolution of arboreal ant communities. Zootaxa 2031:1-20

Emerson AE (1968) A revision of the fossil genus Ulmeriella (Isoptera, Hodotermitidae, Hodotermitinae). Am Mus Novit 2332:1-22

Engel MS, Hinojosa-Diaz IA, Rasnitsyn AP (2009) A honey bee from the Miocene of Nevada and the biogeography of Apis (Hymenoptera: Apidae: Apini). Proc Calif Acad Sci 60:23-39

Fikácek M, Hájek J, Prokop J (2008) New records of the water beetles (Coleoptera: Dytiscidae, Hydrophilidae) from the central European Oligocene-Miocene deposits, with a confirmation of the generic attribution of Hydrobiomorpha enspelense Wedmann, 2000. Ann Soc Entomol France 44:187-199

Gersdorf E (1968) Neues zur Ökologie des Oberpliozäns von Willershausen. Beih Ber Nathist Ges Hannover 6:83-94

Gersdorf E (1976) Dritter Beitrag über Käfer (Coleoptera) aus dem Jungtertiär von Willershausen, B1. Northeim 4226. Geol Jahrb A 36:103-145

Grimaldi D, Engel MS (2005) Evolution of the insects. Cambridge University Press, Cambridge

Grimaldi DA (1992) Vicariance biogeography, geographic extinctions, and the North American Oligocene Tsetse flies. In: Novacek MJ, Wheeler QD (eds) Extinction and Phylogeny. Columbia University Press, New York, pp 178-204

Gupta NS, Briggs DEG, Collinson ME, Evershed RP, Michels R, Pancost RD (2007) Molecular preservation of plant and insect cuticles from the Oligocene Enspel Formation, Germany: Evidence against derivation of aliphatic polymer from sediment. Organ Geochem 38:404-418

Hellmund M, Hellmund W (1993) Neufund fossiler Eilogen (Odonata, Zygoptera, Coenagrionidae) aus dem Oberoligozän von Rott im Siebengebirge. Decheniana 146:348-351
Heyden C von (1862) Gliederthiere aus der Braunkohle des Niederrhein' s, der Wetterau und der Röhn. Palaeontographica 10:62-82

Hickin NE (1967) Caddis Larvae. Hutchinson, London

Hörnschemeyer T, Wedmann S (1994) Fossile Prachtkäfer (Coleoptera: Buprestidae: Buprestinae) aus dem Mitteleozän der Grube Messel bei Darmstadt, Teil 1. Cour Forsch-Inst Senckenberg 170:85-136

Ivany LC, Patterson WP, Lohmann KC (2000) Cooler winters as a possible cause of mass extinctions at the Eocene/Oligocene boundary. Nature 407:887-890

Joachim C (2008) Biodiversität und Palökologie fossiler Insekten des Randecker Maar. Unpublished Diploma thesis. University of Hohenheim, Hohenheim

Kohring R (1991) Eier, Larven- und Puppenstadien fossiler Insekten aus dem Ober-Oligozän von Rott (Siebengebirge). Berliner Geowissensch Abh A 134:187-219

Kohring R, Schlüter T (1993) Sciariden (Insecta: Diptera: Nematocera) aus dem Pliozän von Willershausen. Berl Geowissensch Abh E 9:191-199

Kotthoff U (2002) Fossile Honigbienen (Apis armbrusteri) und andere Angehörige der Holometabola des Randecker Maars. Unpublished Diploma thesis. University of Tübingen, Tübingen

Kotthoff U (2005) Über einige Hymenoptera (Insecta) aus dem UnterMiozän des Randecker Maars (Schwäbische Alb, Südwestdeutschland). Stuttg Beitr Natkd Ser B 355:1-25

Kühbander M, Schleich HH (1994) Odontomyia-Larven aus dem Randecker Maar (Insecta: Diptera, Stratiomyidae). Mitt Bayer Staatslg Paläontol Hist Geol 34:163-167

Lutz H (1990) Systematische und palökologische Untersuchungen an Insekten aus dem Mittel-Eozän der Grube Messel bei Darmstadt. Cour Forsch-Inst Senckenberg 124:1-165

Lutz H (1991) Fossilfundstelle Eckfelder Maar-Beiträge zur Flora und Fauna des Mitteleozäns in der Eifel. Landessammlung für Naturkunde Rheinland-Pfalz, Mainz

Lutz H (1993) Eckfeldapis electrapoides nov. gen. n. sp., eine "Honigbiene" aus dem Mittel-Eozän des "Eckfelder Maares" bei Manderscheid/Eifel, Deutschland (Hymenoptera: Apidae, Apinae). Mainzer Naturwiss Arch 31:177-199

Lutz H (1996) Die fossile Insektenfauna von Rott. Zusammensetzung und Bedeutung für die Rekonstruktion des ehemaligen Lebensraumes aus: W. v. Koenigswald (Hrsg.): Fossillagerstätte Rott bei Hennef im Siebengebirge, 2, erweiterte auflage, Siegburg, Rheinlandia, pp 4156

Lutz H (1997) Taphozönosen terrestrischer Insekten in aquatischen Sedimenten — ein Beitrag zur Rekonstruktion des Paläoenvironments. Neues Jahrb Geol P Abh 203:173-210

Lutz H, Kaulfuß U (2006) A dynamic model for the meromictic lake Eckfeld Maar (Middle Eocene, Germany). Z Deut Geol Ges 157:433-450

Martinez-Delclòs X, Martinell J (1993) Insect taphonomy experiments. Their application to the cretaceous outcrops of lithographic limestones from Spain. Kaupia 2:133-144

Mertz DF, Renne PR, Wuttke M, Mödden C (2007) A numerically calibrated reference level (MP28) for the terrestrial mammalbased biozonation of the European Upper Oligocene. Int J Earth Sci 96:353-361

Meunier F (1921) Die Insektenreste aus dem Lutetien von Messel bei Darmstadt. Abh Hess Geol Landesanstalt 7:1-15

Miller KB (2003) The phylogeny of diving beetles (Coleoptera: Dytiscidae) and the evolution of sexual conflict. Biol J Linn Soc 79:359-388

Mörs T (1995) Die Sedimentationsgeschichte der Fossillagerstätte Rott und ihre Alterseinstufung anhand neuer Säugetierfunde (Oberoligozän, Rheinland). Cour Forsch-Inst Senckenberg 187:1-129

Naumann CM (1987) On the phylogenetic significance of two Miocene zygaenid moths (Insecta, Lepidoptera). Paläontol Z 61:299-308 
Parker AR, McKenzie DR (2003) The cause of 50 million-year-old colour. Proc R Soc Lond B 270(S2):151-153

Piton L (1940) Paléontologie du gisement èocéne de Menat (Puy-deDôme) (Faune et Flore). Thesis. Faculté des Sciences de l'Université de Clermont, Clermont

Piton L, Theobald N (1939) Poissons, Crustacés et insectes fossiles de l'Oligocène du Puy-de-Mur (Auvergne). Bull Mens Soc Sci Nancy, Mémoires 4:77-123

Poschmann M (2006) Köcherfliegen-Larvengehäuse (Trichoptera: Integripalpia) aus der Enspel-Formation (Oberoligozän) des Westerwaldes. Mainzer Naturwiss Arch 44:61-70

Poschmann M, Wedmann S (2005) Spinnen, Heuschrecken und Wasserwanzen aus dem Westerwald. Fossilien 4:234-241

Rasnitsyn AP, Quicke DLJ (2002) (eds) History of Insects. Kluwer, Dordrecht

Rayner RJ (1993) Fossils from a middle Cretaceous crater lake: biology and geology. Kaupia 2:5-12

Schawaller W (1986) Fossile Käfer aus miozänen Sedimenten des Randecker Maars in Südwest-Deutschland (Insecta: Coleoptera). Stutt Beitr Natkd Se B 126:1-9

Schindler T, Wuttke M (2010) Geology and limnology of the Enspel Formation (Chattian, Oligocene; Westerwald, Germany). Palaeobio Palaeoenv 90(1)

Schmied H (2009) Cockroaches (Blattodea) from the middel Eocene of Messel (Germany). Unpublished Diploma thesis. University of Bonn, Bonn

Schweizer MK, Wooller MJ, Toporski J, Fogel ML, Steele A (2006) Examination of an Oligocene lacustrine ecosystem using $\mathrm{C}$ and $\mathrm{N}$ stable isotopes. Palaeogeogr Palaeoclimatol Palaeoecol 230:335-351

Scudder SH (1890) The tertiary insects of North America. Rep US Geol Surv Terr 13:1-734

Stankiewicz BA, Briggs DEG, Evershed RP, Flannery MB, Wuttke M (1997) Preservation of chitin in 25-million-year-old fossils. Science 276:1541-1543

Statz G (1930) Drei neue Insektenarten aus dem Tertiär von Rott am Siebengebirge. Wiss Mitt Ver Naturkde Heimatkde Köln 1:10-14

Statz G (1938) Fünf neue fossile Cerambyciden-Arten aus den mitteloligocänen Ablagerungen von Rott am Siebengebirge. Entomol Blätt 34:173-179

Statz G (1939) Geradflügler und Wasserkäfer der oligozänen Ablagerungen von Rott. Decheniana 99A: 1-102

Statz G (1940) Neue Dipteren (Brachycera et Cyclorrhapha) aus dem Oligozän von Rott. Palaeontographica A 91:120-174

Storch G, Engesser B, Wuttke M (1996) Oldest fossil record of gliding in rodents. Nature 378:439-441

Tröster G (1993) Zwei neue mitteleuropäische Arten der Gattung Tenomerga Neboiss 1984 aus dem Mitteleozän der Grube Messel und des Eckfelder Maares (Coleoptera: Archostemata: Cupedidae). Mainzer Naturwiss Arch 31:169-176

Uhl D, Herrmann M (2010) Palaeoclimate estimates for the Late Oligocene taphoflora of Enspel (Westerwald, W-Germany) based on palaeobotanical proxies. Paleobio Palaeoenv 90(1):

Wappler T (2003) Die Insekten aus dem Mittel-Eozän des Eckfelder Maares, Vulkaneifel. Mainzer Naturwiss Arch Beih 27:1-234

Wappler T (2006) Lutetiacader, a puzzling new genus of cantacaderid lace bugs (Heteroptera: Tingidae) from the Middle Eocene Messel Maar, Germany. Palaeontology 49:435-444

Wappler T, Andersen NM (2004) Fossil water striders from the Middle Eocene fossil sites of Eckfeld and Messel, Germany (Hemiptera, Gerromorpha). Paläontol Z 78:41-52
Wappler T, Ben-Dov Y (2008) Preservation of armoured scale insects on angiosperm leaves from the Eocene of Germany. Acta Palaeontol Pol 53:627-634

Wappler T, Engel MS (2003) The middle Eocene bee faunas of Eckfeld and Messel, Germany (Hymenoptera: Apoidea). J Paleontol 77:908-921

Wappler T, Heiss E (2006a) Flatbugs from the Paleogene limnic sediments. 2. Eckfeld maar (Heteroptera: Aradidae). Mainzer Naturwiss Arch 44:53-60

Wappler T, Heiss E (2006b) Flatbugs from Paleogene limnic sediments. III. Enspel (Heteroptera: Aradidae). Z Arb Gem Öst Ent 58:39-44

Wappler T, Heiss E (2006c) Flatbugs from Paleogene limnic sediments. I. Messel maar (Heteroptera: Aradidae). Polskie Pismo Entomol 75:207-217

Wappler T, Smith VS, Dalgleish RC (2004) Scratching an ancient itch: an Eocene bird louse fossil. Proc R Soc London B 271 [Suppl]:255-258

Wedmann S (1998a) Taphonomie der Bibionidae (Insecta: Diptera) aus der oberoligozänen Fossillagerstätte Enspel (Deutschland). Neues Jahrb Geol P-M 1998:513-528

Wedmann S (1998b) First record of fossil tremecine hymenopterans. Palaeontology 41:929-938

Wedmann S (2000) Die Insekten der oberoligozänen Fossillagerstätte Enspel Westerwald, Deutschland) - Systematik, Biostratonomie und Paläoökologie. Mainzer Naturwiss Arch Beih 23:1-154

Wedmann S (2001) Tropische Insekten im Westerwald? - Insektenfunde aus der Zeit vor 25 Millionen Jahren. Verh Westdt Entomol Tag 2000:307-312

Wedmann S (2005) Annotated taxon-list of the invertebrate animals from the Eocene fossil site Grube Messel near Darmstadt, Germany. Courier Forsch-Inst Senckenberg 255:103-110

Wedmann S, Makarkin V (2007) A new genus of Mantispidae (Insecta: Neuroptera) from the Eocene of Germany, with a review of the fossil record and palaeobiogeography of the family. Zool J Linn Soc 149:701-716

Wedmann S, Yeates D (2008) Eocene records of bee flies (Insecta, Diptera, Bombyliidae, Comptosia): Their paleobiogeographic implications and remarks on the evolutionary history of bombyliids. Palaeontology 51:231-240

Wedmann S, Bradler S, Rust J (2007) The first fossil leaf insect: 47 million years of specialized cryptic morphology and behaviour. Proc Natl Acad Sci USA 104:565-569

Wedmann S, Wappler T, Engel MS (2009) Direct and indirect fossil records of megachilid bees from the Paleogene of Central Europe (Hymenoptera: Megachilidae). Naturwissenschaften 96:703-712

Weidner H (1979) Eine weitere Mitteilung über Termiten aus dem Pliozän von Willershausen, Harz (Insecta, Isoptera). Ber Naturhist Ges Hannover 122:91-95

Wheeler WM (1910) Ants; their structure, development and behavior. Columbia University Press, New York

Willmann R (1976) Panorpa rhenana nom. nov., eine Skorpionsfliege aus dem Oligozän (Insecta, Mecoptera). Neues Jahrb Geol P-M 1976:574-576

Wilson MVH (1980) Eocene Lake environments: Depth and distancefrom shore variation in fish, insect, and plant assemblages. Palaeogeogr Palaeoclimatol Palaeoecol 32:21-44

Zherikhin VV (2002) Insect trace fossils. In: Rasnitsyn AP, Quicke DLJ (eds) History of Insects. Kluwer, Dordrecht, pp 303-324 